developed which is of about the size of a very large cocoanut and probably of ovarian origin (an examination was kindly made by Dr. O. H. Roberts). Menstruation has of late been generally very profuse. Whether owing to the growth of the tumour, or to excessive menstrual losses or to dietetic or other causes, the polycythæmia has recently decidedly lessened.

Dr. A. E. Boycott, who kindly very carefully examined the patient's blood on Nov. 9th, 1906. found the hæmoglobin (by Haldane's method) to be 135 per cent.; there were $7,536,000$ red corpuscles in the cubic millimetre (against $9,000,000$ or $10,000,000$ previously) and only 2900 white cells. Dr. Boycott's differential count of white cells gave lymphocytes 11.6 per cent., intermediates $5 \cdot 2$, large hyalines $4 \cdot 0$, polymorphonuclear neutrophiles $77 \cdot 2$, eosinophiles $0 \cdot 8$, and mast cells $1 \cdot 2$; there were no myelocytes. Owing to the condition of leucopenia present the polymorphonuclear neutrophiles, though relatively increased (as before), only attained the total of 2239 in the cubic millimetre of bloodthat is to say, they numbered about 50 per cent. too few (the excessive total quantity of blood in the body must, however, be taken into account). Examination of the red corpuscles showed no poikilocytosis ; most of them were normal in size (as compared by superposition), but there were a few microcytes; a good many were polychromatophilic; there were a fair number of nucleated red cells (normoblasts) present (Dr. Boycott quickly found ten), all with more or less polychromatophilic cytoplasm. Through the kindness of various colleagues I have had the opportunity of examining other cases of splenomegalic polycythæmia which have been observed in London and $I$ am convinced that the constant presence of normoblasts in fair numbers is a specially noteworthy feature of the blood in the present case.

Another point to be mentioned is that for the last two months or so the patient has complained of a remarkable feeling in her hands, an abnormality in "hygric sensibility" - that is to say, she says whatever she touches with her hands (when her hands are cold, as they often are) feels wet to her. In regard to this condition, which may be termed a "paræsthesia "or "illusion" of hygric sensibility, reference may be made to two Italian papers, "Contributo allo Studio della Illusione Igrica," by E. Ravenna and Montagnini," and "Un altro Caso di Alterata Sensibilita Igrica," by $\mathrm{E}$. Ravenna. ${ }^{5}$ In this connexion it may be noted that the present patient first came under observation suffering from severe erythromelalgia of a lower extremity and that various nervous disorders, some of functional, others of organic origin, have been recorded in other published cases of splenomegalic polycythæmia.

In regard to the etiology of the disease there is one point to which I should now like to refer. Senator in his recent paper ${ }^{6}$ says that J. Bence and A. von Koranyi have both suggested that the hæmoglobin of this class of patients cannot take up as much oxygen as the hæmoglobin from blood of normal persons, but observations on Senator's case did not lend support to this view. The point has not been investigated in my own patient, but in a specimen of blood which was given me from another patient with splenomegalic polycytbæmia Dr. Boycott kindly made a direct estimation of the oxygen capacity. He found that though the oxygen capacity of the hæmoglobin was possibly slightly deficient, the blood as a whole had an oxygen capacity of at least 10 per cent. more than that of a normal man. In a specimen of blood from yet another case of splenomegalic polycythæmia Dr. Boycott found the oxygen capacity of the hæmoglobin to be practically normal.

My best thanks are due to Dr. Boycott for his exceedingly valuable help.

Harley-street, $W$.

4 Rivista di Patologia Nervosa e Mentale, 1902, p. 400. 5 La Riforma Medica (Naples), 1903, vol. xix., p. 1377. B Loc. cit.

Middiesex Hospital.-The treasurers of this hospital have received a further donation of 50 guineas from the Worshipful Company of Merchant Taylors.

Medical Graduates' College and Polyclinic. - Professor 'T. Clifford Allbutt, F.R.S., the Regius professor of physic in the University of Cambridge, will preside at the forthcoming annual dinner of the Medical Graduates' College and Polyclinic on Dec. 12th at 7.15 P.M. at the Trocadéro Restaurant, London, $W$. Tickets can be obtained from Captain Pinch, 22, Chenies-street, W.C.

\section{TWO CASES OF PERFORATED GASTRIC ULCER SUCCESSFULLY OPERATED ON.}

By D. MAOARTNHY, M.A. RInIN., M.D. GlasG., ASSISTAN' SURGEON TO THE WLSTERN INIIRMARY, GLASGOW, ETC.

CASE 1.-The patient, a man, aged 41 years, was admitted to Dr. T. K. Dalziel's male ward in the Western Infirmary, Glasgow, on July 11th, 1906, recommended by Dr. F. Macrae and Dr. James Todd as a case of perforated gastric ulcer. He was a very well-developed, healthy looking man, who until a fortnight before admission had never had any trouble with his stomach, but during that time he had experienced a disagreeable sense of heaviness in the epigastrium. About 6 A.M. on the day of admission, while at work, he was suddenly seized with a griping pain in the abdomen and within a short time the pain was so excessive that he was rolling in agony. He was taken home and Dr. Todd saw him at 10 A.M. Dr. Macrae was called in consultation and advised his immediate removal to the Western Infirmary. He was admitted at 4.30 P.M. and the operation was over by 5.30. On admission his temperature was $101 \cdot 8^{\circ} \mathrm{F}$. and his pulse was 108 . The facies was not typical, but the whole abdomen was rigid, particularly in the epigastrium.

On opening the abdomen in the usual way the stomach was brought into the wound and examined first on the anterior surface, which was quite normal in appearance and smooth on the surface except for the presence of a smal nodule of what was mistaken for a little fat that the operator's finger might have dislodged from the supra-peritoneal layer or from the omentum (the patient was a fat man for his years). Next the posterior surface with the curvatures were passed in review without result, and again the anterior surface was exposed. This little excrescence was still in situ three inches or so from the pylorus and midway between the curvatures. Dr. J.S. Rankin, who was assisting, was asked to sponge it off, both hands of the operator being otherwise engaged. It took him several smart rubbings with a gauze sponge to dislodge it and then the perforation was revealed. What was mistaken for a fat globule was in reality a pioneer granulation formed on the serous surface as the final step in the ulceration. No stomach contents had escaped, at least none of a gross character. The stomach wall was infolded at the point of rupture and two parallel continuous sutures of strong catgut were applied. The immediate area was sponged over and afterwards flushed with saline solution. The wound in the abdominal wall was closed in three layers.

The patient's recovery was uneventful. By the following day his temperature was normal; the pain had absolutely disappeared by the time he had come out of chloroform, and there was nothing to note in his subsequent history. He was dismissed on August 11th.

CASE 2.-The patient, a man, aged 29 years, was admitted to the same ward on Sept. 10tb, 1906, recommended by Mr. E. J. Jones of Alexandria as a case of perforated gastric alcer. He had had no trouble with his stomach until he was over 20 years of age, but from that time onwards he had had intermittent attacks of what he described as an uncomfortable gnawing sensation with a sense of weakness in the upper part of the abdomen, coming on about two hours after meals and accompanied by a good deal of flatulence and "water-brash." Rarely had he sickness or vomiting and never hæmatemesis, nor, to his knowledge, melæna. He did not especially diet himself, but he had learned to avoid potatoes, onions, and vegetables generally, which he found brought on an attack. Latterly the seizures had become much more frequent and severe. There were no special symptoms before the sudden illness that necessitated his admission to hospital. He had breakfast at 9 A.M. (porridge, a poached egg, and a thin slice of bread). Between 11 A.M. and noon he began to feel weak and shortly he was suddenly seized with an extremely severe pain in the epigastrium. He took hot water to relieve the pain but immediately rejected this. He was able to walk to a house about 100 yards off where he got some castor oil; this, too, he imme. diately brought up. No blood was noted in the vomited matter. The pain continued and increased in severity. Dr. A. MacLellan's locum-tenent (Mr. Jones) and assistant saw him and advised his immediate removal to hospital. 
On admission his temperature was $101^{\circ} \mathrm{F}$. and his pulse was 116. His face was pinched and anxious-looking. The abdomen was rigid, the pain on pressure being very severe. I was called up at once and operated, finding on the anterior surface of the stomach towards the pyloric end a clean, punched-out perforation. The aperture was circular, it being as cleanly defined as the lace-hole in a boot before the ring is inserted and of the same size. The ulcer was excised by an elliptical incision an inch in length and the edges of the wound were closed by three rows of continuous suture as in gastro-enterostomy. There was a track of inflamed area from the vicinity of the ulcer leading backwards towards the junction of the liver and the right kidney. The area was visible by the white exudation due to the escape of part of the contents of the stomach. This was carefully wiped away with gauze sponges and then copiously washed out with salt solution. There appeared then so little contamination that it was deemed right to close the abdominal wound cornpletely and to do without draining either tbere or in the flanks. A quantity of the saline solution was purposely left in the peritoneal cavity. After recovering consciousness the patient's pain had disappeared and at the first observation the temperature and pulse bad both declined; his facial appearance was quite different, being free from the pinched and anxious look.

The patient's subsequent history was uneventful. His face for a time had a passively congested look, due doubtless to the manipulation of the parts in the near neighbourhood of the sympathetic plexus. He was dismissed well on Oct. 11th. Glasgow.

\section{$\mathbb{C l i n i t a l}$ 然otes: \\ MEDICAL, SURGICAL, OBSTETRICAL, AND THERAPEUTICAL.}

\section{A CASE OF STRANGULATED HERNIA OPERATED ON UNDER L,OCAL AN.ESTHESIA,}

By Datid B. TodD, M R.C.S. ENG., L.R.C.P. LoND.

THE interest of the following case lies in the complete success of the use of a local anæsthetic in an operation for strangulated hernia occurring in advanced life.

On the morning of Nov. 2nd last I was called to see a man who was said to be in great pain. On arrival at the house I found that the patient, who was a well-nourished man, aged 77 years, had a strangulated inguinal hernia of the right side. Some two hours previously he had been feeding pigs, when on lifting something heavy he suddenly felt a violent pain in the inguinal region. He had been ruptured for years and so at first thought that the old rupture was a little pinched and would go back, but as he had worked at it for two hours without success he thought it necessary to seek medical aid. Morphine was given hypodermically and gentle taxis was tried, but as it became clear that no good was likely to accrue operation was suggested. The patient was unable to make up his mind to undergo the ordeal until later in the day, when Mr. G. G. Parsons having very kindly come over from Westbury the operation was commenced at $8 \mathrm{P} . \mathrm{M}$. On the ground of the patient's great age and the fact that he had a very weak heart it was decided not to give a general anæsthetic, but to use a local anæsthetic and the choice fell upon "anæsthunder," a mixture of betaeucaine, suprarenal extract, and phenol. A line was taken from the pubic spine parallel to Poupart's ligament for three inches, and along this line the local anæsthetic was subcutaneously injected. 20 minims were used, and after an interval of three minutes the skin along the line was incised without pain. Until the gut was reached during the operation (which was not specially interesting except for the action of the local anæsthetic) only 60 minims of the anxsthetic were used. The tissues were carefully injected layer after layer; no pain was felt, and there was hardly any bleeding. When it became necessary to incise the internal ring, where in the circumstances of the operation it would have been dangerous to inject the anæsthetic, pain was severe but fortunately of short duration. The bowel was replaced without much difficulty, one deep stitch was inserted, and the incision in the skin was closed by four superficial sutures. Healing was by first intention, and the stitches were removed upon the eighth day after the operation. Throughout the ccurse of the recovery no pain was felt. The patient is now quite out of danger and in addition has a good prospect of a radical cure.

Bratton, near Westbury, Wilts.

\section{A CASE OF EOTOPIC GESTATION OCOURRING} TWICE IN THE SAME PATIENT, IN BOTH INSTANCES THE UTERUS BEING RETROVER'TED.

By Claulita A. P. Rowse, M.B. Durh.

'THE patient was married and aged 26 years; she had one child, four years old. Three years after the birth of the child she missed two periods. At the end of the second month irregular bæmorrhage set in, with severe pain in the right iliac region, the pain being especially noticed during walking. On examination the uterus was found to be retroverted and enlarged and a cystic swelling was felt behind and to the right of the uterus. A diagnosis of ruptured tubal pregnancy was made. Operation was performed. The right tube was ruptured and the ovum with about a pint of blood clot was found between the two layers of the right broad ligament. This was evacuated by the extraperitoneal method; the ovary and tube were not removed.

The patient did not bacome pregnant again until nine years after the operation. The history of the next gestation was as follows. On August 1st, 1906, I was called in to see the patient, who complained of pain in the left iliac region and over the lower part of the abdomen, with sickness after food; there was amenorrhoea of two months' duration. On physical examination the breasts were tender and slightly enlarged; no secretion could be obtained. The vulvæ were bluish in colour and the uterus was somewhat enlarged and retro. verted. Owing to the extreme tenderness it was impossible to replace the uterus. Ichthyol plugs were applied per vaginam for seven days, the patient remaining in bed. On the $8 \mathrm{tb}$, while straining to pass a motion, severe pain was felt in the lower part of the abdomen, with shooting cramp-like pains in the legs. When seen the patient was in a state of collapse, the skin was cold and blanched, and the face was drawn and anxious. She lay on the left side with the knees bent and the thighs drawn up to the abdomen. Examination under an anæsthetic showed that the uterus was no longer retroverted, but drawn up high into the pelvis and pushed over to the right side. A cystic swelling was found behind and to the left of the uterus.

Operation was performed. The abdomen was opened. Behind and to the left of the uterus was found a large adventitious sac containing the ovum and about a quart of blood clot. The sac was formed by the posterior wall of the broad ligament in front, the ruptured tube above, and the intestines posteriorly. The clot and ovum were removed along with the tube and ovary on that side. The right tube and ovary were found to be bound down by adhesions and were not removed. The patient made a good recovery. Watford.

\section{AMYL NI'LRITE IN H WMOPTYSIS AND IN OTHER H AMORRHAGES : RECENT RESULTS.}

\section{By Francis Hare, M.D. DuRh.,}

IATE CONSTLTING PHYSICIAN TO THE IRISHANE GENERAL HOSPITAL,

LAST year and at the commencement of the present year I published in THE IANCET and elsewhere nine cases in which the inhalation of amyl nitrite had been immediately successful in stopping hæmoptysis. (The first two of the series had been published in the Australasian Medical Gazt tte in October, 1903.) There was no complete failure, but in one case in which there had been three attacks one attack was moderated only, not immediately stopped. This was due to inadequacy of dose. Since then H. C. Colman ${ }^{1}$ in Scotland and E. T. Smith ${ }^{2}$ in Queensland have each published one case, both immediately successful. But it is in France that the method has been chiefly studied. M. J. Rouget ${ }^{3}$ refers

\section{Scottish Medical and Surgical Journal, May, 1905. 2 Australasian Merical Gazetto. June, 1906}

3 Bulletins et M ímoires de la Société Médicale des Hopitaux de Paris, April 20th, 1905. 